\title{
Redescription of the advertisement call of Aplastodiscus arildae (Cruz \& Peixoto) and description of the call of Aplastodiscus weygoldti (Cruz \& Peixoto) with general notes about the genus in Southeastern Brazil (Anura, Hylidae)
}

\author{
Victor G. D. Orrico 1, 2, 3; Ana Maria P. T. Carvalho-e-Silva ${ }^{2}$ \& Sergio P. Carvalho-e-Silva ${ }^{3}$
}

\author{
${ }^{1}$ Corresponding author. \\ ${ }^{2}$ Laboratório de Biossistemática de Anfíbios, Universidade Federal do Estado do Rio de Janeiro. Avenida Pasteur 458, Prédio \\ da Biologia, sala 402, 22290-240 Rio de Janeiro, Rio de Janeiro, Brasil. E-mail: victordill@gmail.com; atelles@unirio.br \\ ${ }^{3}$ Departamento de Zoologia, Instituto de Biologia, Universidade Federal do Rio de Janeiro. Caixa Postal 68044, 21944-970 \\ Rio de Janeiro, Rio de Janeiro, Brasil. E-mail: sergio@biologia.ufrj.br
}

\begin{abstract}
The study of anuran advertisement calls is very significant for it is an important premating premating mechanism. Herein we redescribe the advertisement call of Aplastodiscus arildae from an area near type-locality and describe the advertisement call of $A$. weygoldti comparing them to previously described advertisement calls of species of the genus Aplastodiscus. Both advertisement calls are simple, non-modulated calls, very similar to each other, but significantly different in what matters to call duration. We describe the first distress call registered for the genus, the distress call of $A$. arildae, that does not have rigid form and was only recorded for one individual. Some general notes of the genus Aplastodiscus are given.

KEY WORDS. Distress call; morphological notes; vocalization.
\end{abstract}

\begin{abstract}
RESUMO. Redescrição do canto de anúncio de Aplastodiscus arildae (Cruz \& Peixoto) e descrição do canto de Aplastodiscus weygoldti (Cruz \& Peixoto) com notas morfológicas sobre o gênero no Sudeste Brasileiro (Anura, Hylidae). As vocalizações de anuros são um importante mecanismo de isolamento pré-zigótico, e por isso seu estudo deve ser incentivado. Neste artigo re-descrevemos o canto de anúncio de Aplastodiscus arildae, de uma área mais próxima da localidade tipo e descrevemos o canto de anúncio de $A$. weygoldti comparando-os a cantos previamente descritos de outras espécies do gênero. Ambas as espécies apresentam os cantos de anúncio simples, não-modulados, muito similares, mas significativamente diferentes no que diz respeito à duração da nota. Descrevemos o primeiro "distress call" registrado para o gênero, o "distress call” de A. arildae, que não possui uma forma rígida e foi emitido apenas por um dos indivíduos coletados. Notas sobre o gênero Aplastodiscus são dadas.

PALAVRAS-CHAVE. Distress call; vocalização.
\end{abstract}

FaIvovich et al. (2005) madea cladistic review of the Hylidae family removing several species from the genus Hyla Laurenti, 1768. The Hyla albofrenata group, composed of six species: Hyla albofrenata Lutz, 1924; Hyla arildae Cruz \& Peixoto, 1987; Hyla ehrhardti Müller, 1924; Hyla eugenioi Carvalho-e-Silva \& Carvalhoe-Silva, 2005; Hyla musica Lutz, 1949; and Hyla weygoldti Cruz \& Peixoto, 1987 (Cruz \& Peixoto 1987, Faivovich et al. 2002, Carvalho-e-Silva \& Carvalho-e-Silva 2005), is now placed under the genus A plastodiscus Lutz, 1950 (FAIvovicH et al. 2005).

Simpatry is only known for two species in theAplastodiscus albofrenatus group; among A. musicus and A. arildae in Teresópolis. A plastodiscus musicus, can only befound in altitudes above $1500 \mathrm{~m}$ in the Parque Nacional da Serra dos Órgãos (PARNA/ $\mathrm{SO}$ ) in Teresópolis, Rio de Janeiro state while A. arildae, is found in altitudes above $600 \mathrm{~m}$ in a widespread distribution.
All the species of the genus are very similar in many aspects, presenting as morphological sinapomorphies proportionally large internal metatarsal and metacarpal tubercles, bicolored iris and females with unpigmented eggs for species with known breeding behavior (FalvovicH et al. 2005), except for the A plastodiscus albofrenatus group that does not present bicolored iris as remarked by Carvalho-e-Silva \& Carvalmo-e-Silva (2005).

The species in the Aplastodiscus albofrenatus group have very similar advertisement calls that, according to LuTz (1949), sound like "water dripping in a bottle", except A. musicus that sounds like "an old fashioned glockenspiel", but it is still very similar to the other species advertisement calls.

The study of anuran advertisement calls is important because calling is considered a significant premating isolating mechanism (Pombal et al. 1995, MARTIns \& JIm 2003, 2004), even

Revista Brasileira de Zoologia 23 (4): 994-1001, dezembro 2006 
though all important factors for anuran mate choice are not yet known (Wollerman \& Wiley 2002). It seems that this mechanism evolves fine tuning of a functional system; but, to achieve species isolation trought calls, major changes are not required (HEYER 1980). In order to discriminate two different species, one or more different trait, or combinations of traits, in vocalization is needed (CARDoso \& VieLLARD 1990, Bush et al. 2002, Wollerman \& WILEY 2002).

Four species of the Aplastodiscus albofrenatus group have their advertisement calls described: A. al bofrenatus from Parque Nacional da Tijuca (PNT), Rio de Janeiro, Rio de Janeiro state (Bokermann 1967); A. arildae, from Boracéia, São Paulo state (Heyer et al. 1990); Aplastodiscus eugenioi (then Hyla sp. aff. ehrhardti) from Picinguaba, São Paulo State (HARTMAnn et al. 2004) and Managaratiba, Rio de Janeiro state (CARVALHo-E-Silva \& Carvalho-e-Silva 2005) and A. ehrhardti (Conte et al. 2005). BOKERMANN (1967) also points out the overall similarity among Aplastodiscus cavicola Cruz \& Peixoto, 1985 (as H. albosignata Lutz \& Lutz, 1938) from Bocaina and A. albofrenatus from Tijuca.

Herein we redescribe the advertisement call of Aplastodiscus arildae from an area near the type-locality and describe the advertisement call of A. weygoldti comparing them to previously described advertisement calls of other species of the genus A plastodiscus. We also describe the first distress call registered for the genus and some general notes of the genus Aplastodiscus are given.

\section{MATERIAL AND METHODS}

The data and specimens referring to A plastodiscus arildae were collected in PARNA/SO, Teresópolis, Rio de Janeiro State, during the period from May 2003 to March 2004 and those referring to $A$. weygoldti, were collected in municipality of Domingos Martins, Espírito Santo state, from September to October 1995. The individuals can be found under the numbers 6350; 6477; 9497; 9498; 9499 and 9500 in the Amphibian Collection of the Department of Zoology of Universidade Federal do Rio de Janeiro (ZUFRJ).

It was used a Sennheiser ME-80 directional, active microphone, a Sony WM MC6 tape recorder and cassettetapes TDK chrome 90 minutes to recorde the species in field. The records were made at night, during the moments of higher call activity, and during the breeding season (May to February). The specimens recorded were collected and their snout-vent length (SVL) measured with a $0.1 \mathrm{~mm}$ caliper.

In this work weanalyzed temporal (noteduration and repetition rates) and spectral traits (dominant frequency, fundamental frequency and number of harmonics). Since both species have simple advertisement calls, possessing only a single note with one pulse repeated through time (see DuelLman \& Pyles 1983), the term "note" is used as synonym of "pulse" in this work.

The technical terms used in this work were adapted of those used in Duellman \& Pyles (1983), Cardoso \& Vielliard (1990), Heyer et al. (1990), Littrejohn (2001) and Martins \& Jim (2003).
The data was analyzed with the program Cool Edit v. 96 (Syntrilium Co.), digitalized with a sampling rate of 44100 points in 16 bits mono. Since by definition harmonics are infinite, for practical reasons, only frequencies presenting peaks above $-48 \mathrm{~dB}$ were measured. All data were compared using " $\mathrm{t}$ Student" test with $0.05 \%$ of significance ( $5 \%$ alpha) (ZAR 1984).

\section{RESULTS}

For both species, the typical advertisement call note present itself in the oscillogram, bell-shaped, with attack shorter than decay (see LiTTLEjoHn 2001), and doesn't show modulation in the sonogram (Figs 1-4)

Another type of call, similar to advertisement, but forming a complex call made of three to five notes (similar to Bufo Laurenti, 1768 Bufonidae advertisement calls, but with a higher pitch) was heard, but not recorded. We classified this call as a territorial call, for it was only heard in great choir activity (N >15 approximately). This type of call was also registred for A. albofrenatus (Bokermann 1967) and A. eugenioi (HARTMANn et al. 2004), but was not recorded by BoKERMANn (1967), only remarked, and HARTMANn et al. (2004) didn't classify the call within any call types.

For Aplastodiscus arildae, call data of three captured individuals (ZUFRJ 9497, 9498 e 9499; SVL =40.8, 40.7, $42.1 \mathrm{~mm}$ respectively) and a not captured individual were analyzed.

Individual ZUFRJ 9497 was recorded while calling in the central cup of a bromeliad (Vriesia sp.) and was the only animal calling when captured. All other individuals were in chorus situations but with different densities of heard calling males. The context of chorusing individual ZUFRJ 9499 was smaller $(n=3)$ than the context of chorusing individual ZUFRJ 9498 ( $N>15$ ).

The note duration of advertisement call had an average note length of $26.5( \pm 4.5, \mathrm{~N}=129) \mathrm{ms}$ and did not show a constant number of harmonics, in average $6( \pm 2)$, ranging three to ten and modal number of $6(\mathrm{~N}=99)$. The largest energy concentration was found in the second harmonic (=dominant harmonic) that was in average $2413( \pm 167.8) \mathrm{Hz}$ and fundamental frequency ranged $1100-1300 \mathrm{~Hz}$. (see figures 1 and 2, tables I and II).

A distress call was emitted by one individual in captivity (ZUFRJ 9500). This call has not a rigid form, with length varying according to stimuli, with an average of 19 (nineteen) harmonics at each $500 \mathrm{~Hz}$ of fundamental harmonic. Dominant frequency was $4670.25( \pm 3093.06) \mathrm{Hz}$ ranging from 1694 to $8629 \mathrm{~Hz}$ ( $\mathrm{N}=6$ notes). Another call like this was heard in the field, during the day (CARvalho-E-Silva, S. P. pers. obs.) and this is the first record for this call type in the Aplastodiscus albofrenatus group and for the genus (Figs 5 and 6).

For Aplastodiscus weygoldti, call data of two individuals (ZUFRJ 6350, 6477; SVL $=40$ and $38 \mathrm{~mm}$ respectively) and a not captured individual were analyzed. Note duration was, in average, $46( \pm 10) \mathrm{ms}$. The higher energy concentration (dominant frequency) was found in the second harmonic that was

Revista Brasileira de Zoologia 23 (4): 994-1001, dezembro 2006 


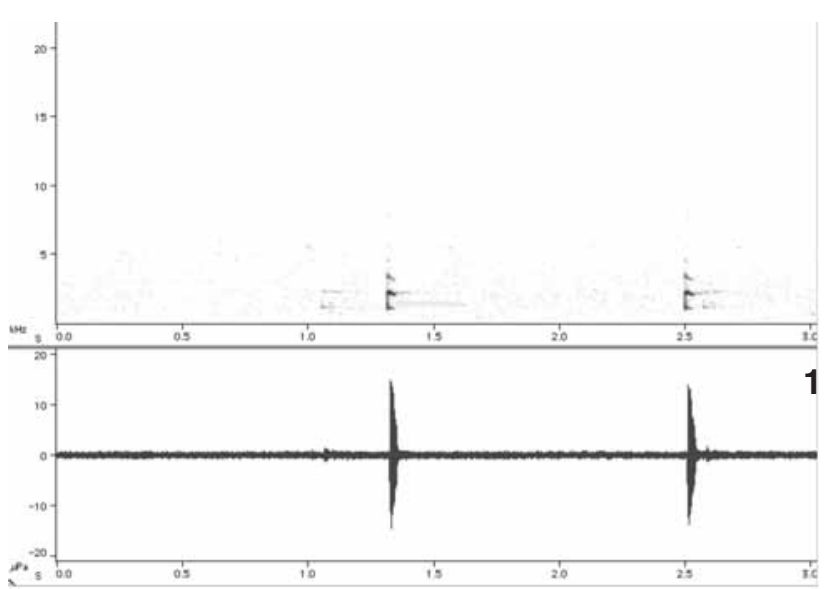

2

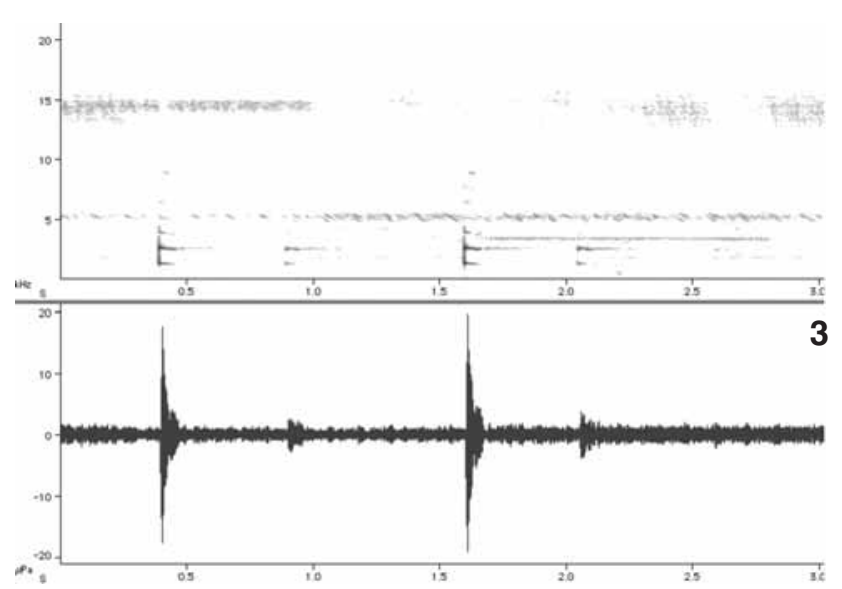

4

Figures 1-4. Sonogram and oscilogram of: (1-2) two advertisement calls of Aplastodicus arildae (ZURFJ 9497); (3-4) Aplastodiscus weygoldti (ZUFRJ 6477) the two less conspicuous calls (with lower intensity) belongs to the not captured individual of A. weygoldti.

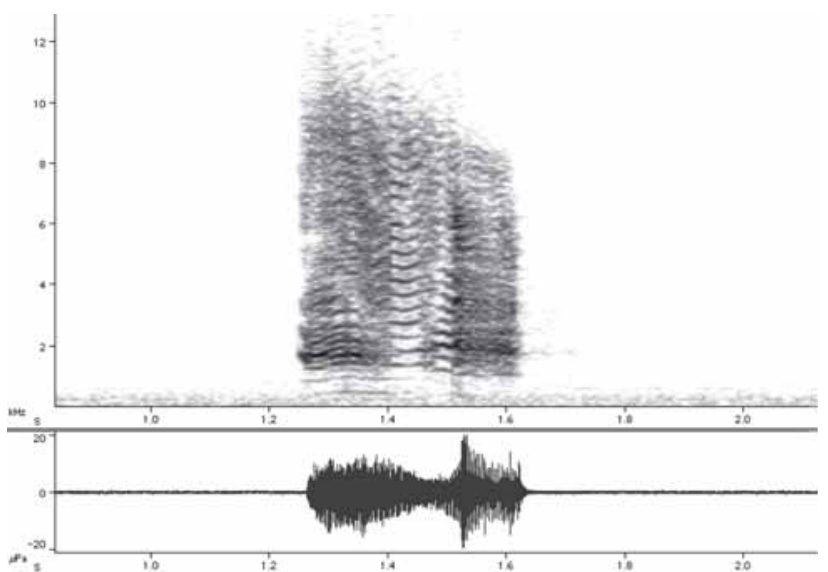

Figures 5-6. Oscilogram and sonogram of Aplastodicus arildae (ZURFJ 9500) distress call.

in average $2591( \pm 42.7) \mathrm{Hz}$ and fundamental frequency always ranged around $1300 \mathrm{~Hz}$. (see figures 3 and 4, tables I and II). The number (amount) of harmonics was $6( \pm 3)$, ranging two to ten with modal number of $7(\mathrm{~N}=85)$.

\section{Temporal traits}

\section{Note duration}

Wollerman \& Wiley (2002) studying recognition error possibilities in Dendropsophus ebracattus (Cope, 1874), realized that only the duration of the primary note of the advertisement call carried recognition information for this species. Cardoso \& Vielliard (1990) found that Hypsiboas punctatus (Schneider, 1799) and $\mathrm{H}$. lanciformis (Cope, 1871) had similar frequency traits for their advertisement calls, but $\mathrm{H}$. Ianciformis call could be recognized by its lower duration.

A plastodiscus arildae advertisement call presented a mean duration of 26.5 ( \pm 4.5 ) ms with high concentration (17\% of variation around the average), while A. weygoldti calls presented a tendency of being longer, meaning 46 (10.1) ms presenting with a lower concentration ( $21 \%$ of variation) around the average. Note duration for $A$. arildae ranged $20-31$ ms against 40 50 ms for A. weygoldti (Tab. I).

Heyer et al. (1990) found that, in Boracéia, note duration for Aplastodiscus arildae ranged $40-60 \mathrm{~ms}$, similar of note duration of $A$. weygoldti herein, but the picture showing a specimen of the species in Boracéia is not a picture of an A. arildae specimen. Both species calls differ from A. albofrenatus call described by BoKERMANn (1967) as a short note with a repetition rate of 40 notes/minute and duration of $50 \mathrm{~ms}$, but, unfortunately, the description in his text doesn't match the data depicted in the published sonogram. Conte et al. (2005) found for A. ehrhardti a note duration of $10.1( \pm 1.2)$ ms ranging $8-13 \mathrm{~ms}$, a lot shorter that the species studied herein.

The advertisement call of Aplastodiscus perviridis, Lutz, 1950 is a short modulated whistle with mean duration of 116 ms (HADDAD et al. 2005), a lot longer then both species of this study. This relation is also true when comparing the advertisement calls of the species herein studied with the call of A. eugenioi in Picinguaba, São Paulo with a mean duration of 85.64 ( \pm 16.77$)$ described by HaRTMAnN et al. (2004) (Tab. I).

The duration of advertisement call was significant as well for Abrunhosa et al. (2005) when studying the Aplastodiscus albosignatus group. With the exception of Aplastodiscus albosignatus and Aplastodiscus ibirapitanga Cruz, Pimenta \& Silvano, 2003, each species has unique call duration. It is important that remains clear that those two species are not sympatric and show different repetition rates and dominant frequencies (see Abrunhosa et al. 2005). 
Table I. Frequencial and note duration data of individuals herein cited. S stands for standard deviation and $\mathrm{N}$ stands for number of unities analyzed. When data was unavaiable it was coded "-". Data from A. ehrhardti are derived from original work.

\begin{tabular}{|c|c|c|c|c|c|c|c|}
\hline Individuals & $\begin{array}{c}\text { Fundamental } \\
\text { frequency }(\mathrm{Hz})\end{array}$ & $\begin{array}{c}\text { Dominant } \\
\text { frequency }(\mathrm{Hz})\end{array}$ & $\mathrm{S}$ & $\mathrm{N}(\mathrm{FF} \& \mathrm{DF})$ & $\begin{array}{c}\text { Note duration } \\
\text { (ms) }\end{array}$ & $\mathrm{S}$ & $\mathrm{N}$ \\
\hline A. arildae 6497 & $=$ Dominant & $\begin{array}{c}1260.1 \\
(1239-1270)\end{array}$ & 8.1 & 28 & $\begin{array}{c}20.1 \\
(19-21)\end{array}$ & 0.6 & 28 \\
\hline A. arildae 6498 & 1200 & $\begin{array}{c}2358.9 \\
(2311-2400)\end{array}$ & 21.3 & 30 & $\begin{array}{c}27.4 \\
(21-32)\end{array}$ & 2.9 & 30 \\
\hline A. arildae 6499 & 1100 & $\begin{array}{c}2245.6 \\
(2120-2280)\end{array}$ & 31.5 & 35 & $\begin{array}{c}31.7 \\
(26-39)\end{array}$ & 3.0 & 35 \\
\hline A. arildae (not captured) & 1300 & $\begin{array}{c}2631.1 \\
(2599-2653)\end{array}$ & 13.7 & 33 & $\begin{array}{c}25.3 \\
(22-29)\end{array}$ & 1.6 & 33 \\
\hline A. weygoldti 6350 & 1300 & $\begin{array}{c}2635.8 \\
(2574-2756)\end{array}$ & 41.7 & 28 & $\begin{array}{c}44.6 \\
(35-43)\end{array}$ & 10.5 & 33 \\
\hline A. weygoldti 6477 & 1300 & $\begin{array}{c}2568.0 \\
(2558-2622)\end{array}$ & 18.0 & 28 & $\begin{array}{c}50.0 \\
(38-61)\end{array}$ & 8.0 & 28 \\
\hline A. weygoldti (not captured) & 1300 & $\begin{array}{c}2553.0 \\
(2284-2615)\end{array}$ & 81.0 & 15 & $\begin{array}{c}40.0 \\
-\end{array}$ & 10.0 & 24 \\
\hline A. eugenioi (HaRTMAnN et al. 2004) & $800-1200$ & $\begin{array}{c}- \\
(2100-2500)\end{array}$ & - & - & $\begin{array}{c}85.64( \pm 16.77) \\
(54-115)\end{array}$ & 16.8 & 46 \\
\hline A. perviridis (HADDAD et al. 2005) & $910-1300$ & $\begin{array}{c}- \\
(2100-2500)\end{array}$ & - & - & $\begin{array}{c}116.0 \\
(97-156)\end{array}$ & 11.0 & 30 \\
\hline A. albofrenatus (BokERMANN 1967) & 1000 & - & - & - & $\begin{array}{c}50.0 \\
(40-60)\end{array}$ & - & - \\
\hline A. ehrhardti (Conte et al. 2005) & $1300-1500$ & $\begin{array}{c}2660.0 \\
(2600-2900)\end{array}$ & - & 40 & $\begin{array}{c}10.1 \\
(8-13)\end{array}$ & - & 40 \\
\hline
\end{tabular}

\section{Repetition rate}

MARTINS \& JIM (2004) found that during the beginning of chorus activities or in isolated male callers of Hyla jimi Napoli \& Caramaschi, 1999 (now Dendropsophus jimi), and H. elianeae Napoli \& Caramaschi, 2000 (now Dendropsophus elianeae) the repetition rates are lower, but during chorus, those rates, as well as the number of notes per call, are higher.

HEYER et al. (1990) found repetition rates for A plastodiscus arildae in Boracéia of 42-102 notes/minute, that are higher than the repetition note recorded for ZUFRJ 9497(29 notes/minute) that was calling alone in the day of recording, but similar to repetition rates of individuals choiring (43-98 notes/minute). Similar data was registered for A. weygoldti as well ( 7.3 notes/ minute when alone and 40-46 notes/minute in chorus). Both species repetition rates, differ from A. eugenioi (as Hyla sp. aff. ehrhardti) repetition rate of 22 notes/minute (HARTMANN et al. 2004), but the authors didn't remark the chorus situation of the recorded specimens. The highest repetition rate was found by CONTE et al. (2005) of 204-264 for A. ehrhardti individuals. Since the sonogram of BoKERMANn (1967) does not agree with his description, we were unable to compare it with our data (Tab. II).
The emission of notes with different temporal traits in chorus situation can be related to the maintenance of individual space among active neighbor males (M ARTINS \& JIM 2003). Our t-Student tests showed that repetition rates in our data, were unique even between the individuals of A. weygoldti recorded together, thus we are able to infer that repetition rates are actively adjusted for each chorus situation.

This phenomenon has already been observed for other species within Hylidae family: Dendropsophus nanus (Boulenger, 1889), Dendropsophus sanborni (Schmidt, 1944), (M ARTINS \& JIM 2003), Scinax argyreornatus (Miranda-Ribeiro, 1926) and $S$. rizibilis (Bokermann, 1964) (PomBAL et al. 1995). It is al so known for, at least, two others species within Leiuperidae Bonaparte, 1850 family: Engystomops pustulosus (Cope, 1864) and E. petersi Jiménez de la Espada, 1872 (Ryan \& Rand 2001).

When we analyzed the variation coefficients of call interval from animals that were in chorus activity and calling alone it was possible to notice some tendency of chorusing animals to call more regularly. "Lonely-callers" coefficients of variation ranged between 27-59\% (ZUFRJ 9497 and ZUFRJ 6350), while "chorus-callers" presented a variation of $13.7-31 \%$ (A. arildae not captured individual and ZUFRJ 9499). CARDoso 
Table II. Interval call data of individuals herein cited. S stands for standard deviation and N stands for number of unities analyzed. Interval is the time elapsed between the beginning of two calls. When data was unavaiable it was coded "-". Data from A. ehrhardti are derived from original work.

\begin{tabular}{|c|c|c|c|c|c|}
\hline Individuals & Intervals between calls & $\mathrm{S}$ & $\mathrm{N}$ & $\begin{array}{l}\text { Variation coefficient of } \\
\text { intervals }(\mathrm{S} / \mathrm{X}) * 100\end{array}$ & $\begin{array}{c}\text { Repetition rate } \\
\text { (notes/min) }\end{array}$ \\
\hline \multirow[t]{2}{*}{ A. arildae 6497} & $00: 02.125$ & $00: 00.570$ & 27 & 27 & 29 \\
\hline & $(00: 00.993-00: 03.225)$ & & & & \\
\hline \multirow[t]{2}{*}{ A. arildae 6498} & 00:00.980 & $00: 00.137$ & 29 & 14 & 60 \\
\hline & (00:00.716-00:01.208) & & & & \\
\hline \multirow[t]{2}{*}{ A. arildae 6499} & 00:01.437 & 00:00.448 & 35 & 31 & 43 \\
\hline & $(00: 00.862-00: 02.680)$ & & & & \\
\hline \multirow[t]{2}{*}{ A. arildae (not captured) } & 00:00.611 & 00:00.079 & 34 & 13 & 100 \\
\hline & $(00: 00.470-00: 00.901)$ & & & & \\
\hline \multirow[t]{2}{*}{ A. weygoldti 6350} & 00:08.395 & 00:04.982 & 32 & 59 & 7 \\
\hline & $(00: 00.00-00: 22.425)$ & & & & \\
\hline \multirow[t]{2}{*}{ A. weygoldti 6477} & 00:01.366 & 00:00.301 & 27 & 22 & 43 \\
\hline & (00:01.008-00:01.972) & & & & \\
\hline A. eugenioi (HaRTMAnN et al. 2004) & - & - & - & - & 22 \\
\hline \multirow[t]{2}{*}{ A. perviridis (HADDAD et al. 2005) } & 00:00.469 & $00: 00.228$ & 30 & 49 & 120 \\
\hline & $(00: 00.343-00: 01.609)$ & & & & \\
\hline \multirow[t]{2}{*}{ A. eugenioi (Conte et al. 2005) } & $00: 00.269$ & - & 40 & - & 204264 \\
\hline & $(00: 00.206-00: 00.337)$ & & & & \\
\hline
\end{tabular}

\& Vielliard (1990) also noted some difference among lonely and chorus callers in Hypsiboas punctatus but didn't pay much attention to it. We did not analyze call interval of not-captured A. weygoldti. This individual was recorded in ZUFRJ 9499 track as background so; due to the high level of noise; we were unable to define precisely the temporal limits for several notes. The amount of definable intervals was too low $(\mathrm{N}=5)$ and we preferred to exclude this individual for this analysis. So, CONTE et al (2005) probably recorded two chorusing animals since the variation coefficients of call intervals of both their individuals were around $10 \%$ according to their data.

For future works, we strongly recommend that chorus situation should be elicited when describing amphibian advertisement calls.

\section{Spectral traits}

Both species advertisement calls herein depicted differ from Aplastodiscus perviridis, for they don't present modulated calls as described by HADDAD et al. (2005) for this specie. With the exception of A. cavicola, all species within the Aplastodiscus albosignatus group have non-modulated calls (see ABRUNHOSA et al. 2005). In accordance to FaIvovich et al. (2005) we also think that only future research will define whether any character state related to the advertisement calls could be considered as a synapomorphy of the genus A plastodiscus, or of any of its internal clades.

\section{Dominant frequencies}

A plastodiscus arildae and A. weygoldti emit advertisement calls with dominant frequency in the second harmonic ranging $2120-2653 \mathrm{~Hz}$ for $\mathrm{A}$. arildae and $2284-2756 \mathrm{~Hz}$ for $\mathrm{A}$. weygoldti. HARTMANN et al. (2004) do not remark a dominant frequency for A. eugenioi in Picinguaba, SP but the sonogram in their work clearly shows a dominant frequency in the second harmonic even though there is not a spectrogram available. This dominant frequency in the second harmonic of the advertisement call may be the plesiomorphic state for this character for the genus since all known advertisement calls of Aplastodiscus albofrenatus and A. perviridis groups (except for A. albofrenatus for that in it's original sonogram nothing is mentioned) present this character but, the species of the Aplastodiscus albosignatus group present dominant frequencies in the third and/or in the fundamental harmonic (ABRUNHOSA et al. 2005). Five calls of one individual of A. weygoldti (ZUFRJ 6350) presented the dominant frequency in the fundamental harmonic, but the amount of energy of this harmonic was practically the same of the second harmonic, just a little bit higher.

Cardoso \& Vielliard (1990) could not differ Osteocephalus subtilis Martins \& Cardoso, 1987 and Hyla punctata calls only for its temporal structure, but they were easily separated for their dominant frequencies. We were not able to separate A. ehrhardti and A. weygoldti using the dominant frequency as 
Table III. P values for Dominant frequencies T-Student test. * Not captured.

\begin{tabular}{|c|c|c|c|c|c|c|c|c|}
\hline & ZUFRJ 6350 & ZUFRJ 6477 & A. weygoldti * & ZUFRJ 9497 & ZUFRJ 9498 & ZUFRJ 9499 & A. arildae* & \\
\hline ZUFRJ 6350 & 1 & $>0.001$ & $>0.001$ & $>0.001$ & $>0.001$ & $>0.001$ & $>0.001$ & \multirow{7}{*}{ Found critical $P$} \\
\hline ZUFRJ 6477 & 2.014 & 1 & $>0.001$ & $>0.001$ & $>0.001$ & $>0.001$ & $>0.001$ & \\
\hline A. weygoldti * & 2.037 & 2.060 & 1 & $>0.001$ & $>0.001$ & $>0.001$ & $>0.001$ & \\
\hline ZUFRJ 9497 & 2.030 & 2.024 & 2.069 & 1 & $>0.001$ & $>0.001$ & $>0.001$ & \\
\hline ZUFRJ 9498 & 2.010 & 2.004 & 2.056 & 2.024 & 1 & $>0.001$ & $>0.001$ & \\
\hline ZUFRI 9499 & 2.001 & 2.002 & 2.048 & 2.020 & 1.999 & 1 & $>0.001$ & \\
\hline A. arildae* & 2.024 & 2.010 & 2.064 & 2.002 & 2.011 & 2.011 & 1 & \\
\hline
\end{tabular}

character. Both species present this second harmonic around 2600 (Tab. I). Actually, our T-Student tests (95\%) showed that dominant frequencies were individual for each animal in this study (Tab. III). Due to the low number of captured individuals, it was not possible to make a relation between animal size and dominant frequency. But as general information, at least for Aplastodiscus arildae, larger animals seem to have lower dominant frequencies. One individual (ZUFRJ 9497) whose average dominant frequency was $1260.1( \pm 8.1) \mathrm{Hz}($ Tab. I) is the exeption, but it is important to remark that this particular individual was record calling inside the cup of a bromeliad and this may have had an influence in the signal. For this animal, the vegetation, or thinking more specifically, the calling site choice produced an alteration in his specific signal as happened with Centrolenella fleischmanni (Boetger) Centrolenidaein WelLS \& SchwarTz (1982) study.

Fundamental harmonic

The fundamental harmonic of the herein studied species of A plastodiscus ranged $1100-1300 \mathrm{~Hz}$ (while A. weygoldti always presented $1300 \mathrm{~Hz}$ ).

Aplastodiscus perviridis has a fundamental frequency of 910-1300 Hz (HADDAD et al. 2005), A. albofrenatus is according to original sonogram (BOKERMANN 1967) is $1000 \mathrm{~Hz}$, A. eugenioi presents fundamental harmonic that ranges from 800 to 1200 $\mathrm{Hz}$ (Hartmann et al. 2004), A. ehrhardti 1300-1500 Hz and the A. albosignatus group ranges $700-1040 \mathrm{~Hz}$ (ABRUNHOSA et al. 2005).

Like dominant harmonics, fundamental harmonics couldn't separate the species.

\section{Number of harmonics}

One captured individual (ZUFRJ 9499) and one not captured of Aplastodiscus weygoldti presented fewer harmonics in sonogram then other co-specific recorded males, especially higher harmonics. That absence of higher harmonics may have happened because some environment factors, such as the vegetation between the animal and the microphone, may interfere in signal quality by reflection or amortization (WELLS \& Schwartz 1982, Duellman \& Trueb 1986, Cardoso \& Viellard 1990), and, since every time the distance between source and receiver doubles, the signal loses 6 dB (Wollerman 1999), fre- quencies with lower amount of energy should fade out first.

In a general matter, the number of harmonics were or too variable (variation coefficients $=3.5-40.03 \%$ for $\mathrm{A}$. arildae and $23.5-42.58 \%$ for $A$. weygoldti) to assure a specific relationship.

Nevertheless, modal numbers had shown (at least in Aplastodiscus albofrenatus group described calls and for A. perviridis) a specific number of harmonics per species. Aplastodiscus ehrhardti presented the smaller number of harmonics (two to four) according to (CONTE et al. 2005) followed by A. eugenioi (= Hyla sp. aff. ehrhardti, HARTMANn et al. 2004) (three harmonics), and A. perviridis with four harmonics (HADDAD et al. 2005). The species herein studied presented modal number of six (A. arildae) and seven (A. weygoldti) harmonics. Even though we are comparing modal numbers in our data with mean numbers for the previously described calls, we figure that this character may be elucidative if calls, in the future, have more standardized recordings.

\section{GENERAL CONSIDERATIONS}

\section{Types of calls}

Aplastodiscus perviridis also presents three types of courtship calls (HADDAD et al. 2005) that were not observed by us in neither of our studied species, but we were not able to presence the whole breeding behavior of those species. Males of A. perviridis studied by HADDAD et al. (2005) shown four types of calls (announcement + three different courtship calls), A. eugenioi studied by HARTMANN et al. (2004) showed three (announcement + two) and A. albofrenatus by BoKERMAnN (1967) presented two types (announcement +one), A. weygoldti also presented the same two types of A. albofrenatus (advertisement and territorial) and A. arildae presented three types: advertisement, territorial and distress call. This is the first record of a distress call for the Aplastodiscus genus.

Even though HEYER (1980) affirms that morphological resemblance indicates a high level of filetic relationship, StRAUGHAN (1973) says that parallelism and convergence problems may appear just like any other character, so, homologies can't be based only in vocalizations because similar calls can be produce by completely different apparatus and vice versa. 


\section{Morphological remarks}

Carvalho-e-Silva \& Carvalho-e-Silva (2005) remarked that the species in the Aplastodiscus albofrenatus group have a redorange iris. In our observations, A. arildae and A. weygoldti presents a bi-colored iris characteristically with a 'ring' (for the pupil is elliptical). Even though the internal 'ring' has a smaller radius comparing to the other species of the genus similar to the species in A plastodiscus albosignatus group (see ABRUNHOSA et al. 2005). This ring may be gray as affirmed by CARVALHO-E-Si LVA \& CARVALHO-E-SILVA (2005) for the A plastodiscus al bosignatus group or presenting a lighter coloration in comparison to the external ring, tending to white.

\section{AKNOWLEDGEMENTS}

To Itamar A. Martins, Luis N. Weber, Adriano L.C. Pinto, Roberta R. Pinto, Luiz A.P. Gonzaga e Sergio R. dos Santos.

\section{REFERENCES}

Abrunhosa, P.A.; B.V.S. Pimenta; C.A.G. Cruz \& C.F.B. Haddad. 2005. Advertisement Calls of Species of the Hyla albosignata Group (Amphibia, Anura, Hylidae) Arquivos do Museu Nacional, Rio de Janeiro, Rio de Janeiro, 63 (2): 275-282.

BoKERMANN, W.C.A. 1967. Notas sobre cantos nupciais de anfíbios brasileiros. I. (Anura). Anais da Academia Brasileira de Ciências, Rio de Janeiro, 39 (3/4): 438-443.

Bush, S.L.; H.C. Gerhardt \& J. Schul. 2002. Pattern recognition and call preferences in tree frogs (Anura: Hylidae): A quantitative analysis using a no-choice paradigm; Animal Behavior, Nottingham, 67:1-14.

Cardoso, A. \& J. Vielliard. 1990. Vocalizações de anfíbios anuros de um ambiente aberto, em Cruzeiro do Sul, estado do Acre. Revista Brasileira de Biologia, São Paulo, 50 (1): 229-242.

Carvalho-e-Silva, A.M.P.T. \& S.P. Carvalho-e-Silva. 2005. New Species of the Hyla albofrenata Group, from the States of Rio de Janeiro and São Paulo, Brazil (Anura, Hylidae) Journal of Herpetology, Columbus, 39 (1): 73-81.

Conte, C.E. ; R. Lingnau \& A. Kwet. 2005. Description of the advertisement call of Hyla ehrhardti Müller, 1924 and new distribution records (Anura: Hylidae). Salamandra, Rheinbach, 41 (3): 147-151.

Cruz, C.A. \& O.L. Peixoto. 1987. Espécies verdes de Hyla: o complexo "Albofrenata” (Amphibia; Anura; Hylidae). Arquivos da Universidade Federal Rural do Rio de Janeiro, Seropédica, 8 (1/2): 59-70.

Duellman, W.E. \& R. A. Pyles. 1983. Acoustic Resource Partitioning in Anuran Communities, Copeia, Lawrence, TX, 3: 639649.

Duellman, W.E. \& L. TRueb. 1986. Biology of amphibians. New York, McGraw-Hill Book, 670p.

Falvovich, J.; C. A Cruz \& O. L. Рeixoto. 2002. The identity of Hyla ehrhardti (Anura, Hylidae). Journal of Herpetology, Columbus, 36 (2): 325-327.
Faivovich, J.; C.F.B. Haddad; P.C. A. Garcia; D.R. Frost; J.A. Campbell \& W.C. Wheeler. 2005. Systematic review of the frog family Hylidae, with special reference to Hylinae: Phylogenetic analysis and taxonomic revision. Bulletin of the American Museum of Natural History, American Museum of Natural History, New York, 294: 1-240.

Haddad, C.F.B.; J. Falvovich \& P.C. A. Garcia. 2005. The specialized reproductive mode of the tree frog A plastodiscus perviridis (Anura: Hylidae). Amphibia Reptilia, Koninklike Brill NV, Leiden, 26: 87-92.

Hartmann, M.T.; P.A. Hartmann \& C.F.B. Haddad. 2004. Visual signaling and reproductive biology in a nocturnal treefrog, genus Hyla (Anura: Hylidae). Amphibia Reptilia, Koninklike Brill NV, Leiden, 25: 395-406.

Heyer, R.W. 1980. The calls and taxonomic position of Hyla gieslei and Ololygon opalina (Amphibia, Anura, Hylidae). Proceedings of the Biological Society of Washington, Washington, 93 (3): 655-661.

Heyer, R. W.; A. Rand; C.A. Cruz; O.l. Peixoto. \& C. Nelson. 1990. Frogs of Boracéia. Arquivos de Zoologia, São Paulo, 31 (4): 231-410.

LitTlejohn, M.J. 2001. Patterns of differentiation in temporal properties of acoustic signal of anurans, p. 102-120. In: M.J. Ryan (Ed.) Anuran communication. Washington, Smithsonian Institution Press, 250p.

LuTz, B. 1949. Anfíbios anuros da coleção Adolpho Lutz. II. Espécies verdes do gênero Hyla do leste-meridional do Brasil. Memórias do Instuto Oswaldo Cruz, Rio de Janeiro, 46: 550-577.

MARTINS, I.A. \& J. JIM. 2003. Bioacoustic analysis of advertisement call in Hyla nana and Hyla sanborni (Anura, Hylidae) in Botucatu, São Paulo Brazil. Brazilian Journal of Biology, São Paulo, 63 (3): 507-516.

Martins, I.A. \& J. Jım. 2004. Advertisement call of Hyla jimi and Hyla elianeae (Anura: Hylidae) in the Botucatu region São Paulo, Brazil. Brazilian Journal of Biology, São Paulo, 64 (3B): 645-645.

Pombal JR, J.P.; R.P. Bastos \& C.F.B. Haddad. 1995. Vocalizações de algumas espécies do gênero Scinax (Anura, Hylidae) do sudeste do Brasil e comentários taxonômicos. Naturalia, São Paulo, 20: 213-225.

RYAN, M.J. \& A.S. RAND. 2001. Feature weighting in signal recognition and discrimination by Túngara frogs, p. 86-101. In: M.J. RyAN (Ed.). Anuran communication. Washington, Smithsonian Institution Press, 250p.

Straughan, I.R. 1973. Evolution of anuran mating calls bioacoustical aspects, p. 321-327. In: J.L. VIAL (Ed.) Evolutionary biology of the Anuran. Columbia, University of Missouri Press, 758p.

WelLS, K.D. \& J.J. Schwartz. 1982. The effect of vegetation on propagation of calls in the neotropical frog Centrolenella fleischmanni - Herpetologica, Lafayette, 38 (4): 449-455.

Wollerman, L. 1999. Acoustic interferencelimits in call detection 
in a Neotropical frog Hyla ebraccata. Animal behavior, Nottingham, 57: 529-536.

Wollerman, L. \& R.H. WiLEY. 2002. Possibilities for error during communication by Neotropical frogs in a complex acoustic environment. Behavioral Ecology Sociobiology, SpringerVerlag, 52: 465-473.

ZAR, J.H. 1984. Biostatistical Analysis. New Jersey, PrenticeHall, 663p.

Received in 17.I.2006; accepted in 13.XI.2006. 